\title{
Research self-efficacy of lecturers in non-university higher education
}

\author{
Author(s) \\ Griffioen, D.M.E.; de Jong, U.; Jak, S. \\ DOI
}

10.1080/14703297.2012.746512

\section{Publication date}

2013

Document Version

Author accepted manuscript (AAM)

Published in

Innovations in Education and Teaching International

Link to publication

\section{Citation for published version (APA):}

Griffioen, D. M. E., de Jong, U., \& Jak, S. (2013). Research selfefficacy of lecturers in non-university higher education. Innovations in Education and Teaching International, 50(1), 25-37.

https://doi.org/10.1080/14703297.2012.746512

It is not permitted to download or to forward/distribute the text or part of it without the consent of the author(s) and/or copyright holder(s), other than for strictly personal, individual use, unless the work is under an open content license (like Creative Commons). 
This is the post-print version, which is published as: D.M.E. Griffioen, U.de Jong, and S. Jak (2013). Research self-efficacy of lecturers in non-university higher education. Innovation in Education and Teaching International 50(1), 25-37. For the published version see:

\title{
Research self-efficacy of lecturers in non-university higher education
}

D. M. E. Griffioen ${ }^{\mathrm{a} *}$, U. de Jong ${ }^{\mathrm{b}}$ and S. Jak ${ }^{\mathrm{b}}$

${ }^{a}$ Staff Department Education and Applied Research, Amsterdam University of Applied Sciences, The Netherlands $;{ }^{b}$ Department of Education, University of Amsterdam, The Netherlands

\begin{abstract}
During the last decade, the relationship between university and non-university higher education institutions has changed. As a contribution to the knowledge economy, non-university higher education institutions are expected to educate their students in research activities. Previously, teaching was the main responsibility of lecturers in non-university higher education, while research hardly played a role. This paper is about the belief of lecturers in non-university higher education in their own research ability (research self-efficacy). In a survey study conducted among Dutch lecturers $(\mathrm{N}=790)$, the research selfefficacy has been measured. A Structural Equation Model shows the effects of personal aspects, mastery experience, and organisational context on the research self-efficacy of lecturers. Research self-efficacy is also modelled in relation to lecturers' need to work on professional development in research skills. Results show that research self-efficacy is mostly affected by aspects of mastery experience, in which the context is similar to the given task. Implications are discussed.
\end{abstract}

Key words: lecturers; research efficacy; non-university; higher vocational education.

\section{Introduction}

During the last decade, the relationship between university and non-university higher education institutions has changed in European countries (Kyvik, 2004; Kyvik \& Skodvin, 2003; Witte, Van der Wende, \& Huisman, 2008). One of the issues was whether institutions other than

\footnotetext{
${ }^{*}$ Corresponding author. Email: D.M.E.Griffioen@ @va.nl
} 
universities should be involved in research activities and if so, what these activities should be (Kyvik 2004). In the Netherlands, research activities were virtually non-existent in the past and the means were mostly absent in the non-university institutions (hogescholen) (Witte, Van der Wende \& Huisman, 2008), while research skills and/or experience usually constituted no ground for selection in application procedures for lecturers (de Jong \& de Jager, 2007). Today, lecturers at these institutions are increasingly expected to be involved in research activities (Kyvik \& Skodvin, 2003). The focus of this research is on how lecturers judge their own research ability, since conducting research is a new activity for non-university institutes of higher education. Lecturers' beliefs about their ability to perform the new tasks influence their performance, as lecturers to students in research aspects, but also their own performance as (new) researchers. Beliefs in their own capabilities therefore influence the change of the nonuniversity higher education institutions into more research-based organisations (Runhaar, Sanders \& Yang, 2010).

\section{Conceptions of research self-efficacy}

Self-efficacy is concerned with people's own beliefs in their capabilities to produce given attainments in given contexts (Bandura, 2006). Self-efficacy is different from 'outcome expectancy', which is directed at the consequences of a performed task and not at one's ability to perform. Self-efficacy is also different from other 'conceptions of self', such as self-esteem, self-worth, or self-concept. The construct of self-efficacy is based on the self-perception of the competence, rather than on the actual level of competence (Bandura, 1997; Bandura, 2006; Tschannen - Moran \& Hoy, 2007).

The content of this study is about the belief of lecturers in their own ability to conduct research (research self-efficacy), and not about their ability to teach (teaching self-efficacy). 
Previous research (Dembo \& Gibson, 1985; Tschannen - Moran and Hoy 2007) has shown that several factors are important in explaining the self-efficacy of lecturers. These factors are here divided into three categories: 1) personal factors, 2) factors of mastery experience, and 3) the work context of the lecturer. Since studies on research self-efficacy are relatively scarce, both studies on research self-efficacy and on teaching self-efficacy will be used as guidelines for formulating expectations for the present research.

\section{Personal factors}

Tschannen-Moran and Hoy (2007) included both age and gender in their research, as part of a larger group of demographic variables. Neither of these variables showed a significant relationship with teaching self-efficacy. Still, we included these variables as control factors, because age and gender are part of the broader discussion on the accessibility of research as a profession (Brouwer, 2003). We expected a positive relation between research self-efficacy and age (H1), because Mastery increases over time. Women are expected to score lower on research self-efficacy than men $(\mathrm{H} 2)$, because female traits are usually more modest than male traits (Noble, 1987).

\section{Factors of mastery experience}

Lecturers with a university master's degree have gained experience of doing research during their education. Others may have had the possibility to gain mastery experiences elsewhere. Having no Master's degree and still having experience in research is expected to be relatively rare, since most research-related jobs in the Netherlands expect a Master's degree as lowest qualification. In previous research, the educational level of lecturers had no effect on teaching self-efficacy. Dembo and Gibson (1985) mention that the efficacy scores of preservice teachers 
in elementary school increased with a higher level of education. It is therefore expected that educational level will have a positive effect on the research self-efficacy of lecturers (H3).

Henson (2001) found a relation between involvement in teacher research and an increase in teaching self-efficacy of lecturers. Since involvement in research and research self-efficacy are more similar than research and teaching, this relation is supposed to be present in this study as well. The involvement in research within one's own institution has been made contextspecific to be sufficiently tailored to 'to access the multifaceted ways in which efficacy beliefs operate' (Bandura, 2006). Also it is expected that in the four contexts in which involvement in research activities are possible, involvement will have a positive relation with the lecturers' sense of research self-efficacy (H4). Another way to gain mastery experience in research is by being involved in research outside one's own institute. The expectation is that this experience also positively contributes to the lecturers' sense of research self-efficacy (H5).

The number of years of experience in educational contexts relates to the research on novice and more experienced lecturers. Tschannen-Moran and Hoy (2007) show that experienced lecturers rate themselves significantly higher than novice lecturers on instructional strategies and classroom management. However, several other researchers found a negative correlation between teaching efficacy and teaching experience (Dembo \& Gibson, 1985; Ghaith \& Yaghi, 1997; Hoy \& Spero, 2005). Dembo and Gibson (1985) explain this negative correlation as: an increase in teaching ability can result in a decrease in the trust that good teaching will enable a student to learn. The correlation between years of teaching experience and research efficacy can therefore be positive but also negative (H6).

\section{Work related factors}

Busch, Fallan and Pettersen (1998) included four different disciplines in their research on the performance of lecturers. In the present study, we expect differences between the disciplines. 
The Health Sciences (contrary to the results of Busch, Fallan \& Pettersen, 1998) and lecturers in Social Work are expected to score highest on research self-efficacy, because these disciplines have the longest tradition of doing research in the non-university higher education institutions in the Netherlands; the Economists are expected to score lowest, because their tradition in doing research in non-university higher education is shortest, mainly because of a highly developed research field within the research universities (see for instance Netherlands Economic Institute, 2011) (H7).

Previous research did not consider the length of employment as a lecturer at the current institution. We expect that an increase in years of working at the same institution can have a negative influence on the research self-efficacy of lecturers, especially because the research culture in non-university higher education still is less developed than, for instance, in research universities (Griffioen \& Boei, 2010) (H8).

\section{The need for professional development}

The research on the relation between self-efficacy and the need to be trained shows diverse results. Runhaar, Sanders and Yang (2010) argue that the higher the self-efficacy of lecturers is, the more open they are to new ideas and changes, and the more they are engaged in professional learning activities. They have found a positive relation between lecturers' selfefficacy and their reflection and feedback-asking activities. Similar effects have been found by Clifton (1997) on a group of non-lecturers, and DeForest and Hughes (1992) who found that lecturers with low self-efficacy responded less favourably to consultation activities. Noe and Wilk (1993) also theorise on this relation, but they did not find it in research. They found an indirect relation, but only for one of their three research samples. This implies a (indirect) relation between self-efficacy and the need to professionalize. There are also indications for the relationship being more complex, where a lower degree of self-efficacy results in a higher need 
to be educated (see also Tschannen - Moran \& Hoy, 2007 on novice lecturers). Therefore, the expectancy is that research self-efficacy has a direct effect on the need to be educated in research, but that the sign of this effect is unclear (H9).

\section{Method}

\section{Sample}

During 2008, all employees of four regionally spread non-university higher education institutions, and four social sciences-oriented faculties (including professions such as Economics, Social Work, Law, etc.) of a fifth institution were asked to complete an extensive questionnaire on research-related topics. This research includes only the responses of lecturers who have scores on all variables $(\mathrm{N}=790)$. Since the data was gathered by employees of the institutions themselves, the response ratio remains somewhat unclear. The most conservative estimate is a response ratio of $20 \%$, based on the lists of email addresses provided by the institutes. Usually, the email files used in this matter are not fully up-to-date, by which a more realistic response rate will be 30-35\% (Hofman et al., 2002). Because the bounced invitations were not visible for the researchers, it was beyond their influence to make a more sophisticated estimate. Of the respondent lecturers, most are men (58\%), and most have a university degree (65\%), of whom $6.5 \%$ have completed a $\mathrm{PhD}$. The largest group teaches in the Economics sector $(23 \%)$ and the smallest group in the Arts sector (5\%). The mean age is 47 years (range 21-68). The range of age and gender can be considered average, when looked at national numbers (HBO-raad, 2010), there is no registration on educational level.

\section{Measures}

The research-related activities by the lecturers can consist of two different situations: first, within the regular curriculum of professional bachelor programmes, where research skills are 
among the competencies students must acquire. And second, outside of the curriculum, were a proportion of the teaching staff is involved in research as a new activity separate from their teaching tasks.

\section{Insert table 1 about here}

The combination of the four defined research contexts and five defined research aspects (see table 1, and also Griffioen \& De Jong 2007; 2008) resulted in a scale with 20 items (Likert 4): 'total research self-efficacy’ $(\mathrm{C}$. Alpha $=.97)$, which is confirmed by a principal component analysis in SPSS 18. For all four contexts it is asked whether or not one takes part in research activities (yes/no), and if one has the need to be trained in research (yes/no). Also, personal aspects (gender, age), aspects of mastery experience (educational level, years of employment at this institution, years of working in educational surroundings, currently doing research elsewhere) and the discipline of employment are measured.

\section{Analysis}

First, the results on research self-efficacy and need for professional development are described. Then, to answer the research question, structural equation modelling was used to fit a path model based on the hypotheses (figure 1) to the variance-covariance matrix of all observed variables (to be requested). The path model was tested in a confirmative procedure, using Mplus (Muthén \& Muthén, 2007). Maximum likelihood estimation (ML) was used to obtain parameter estimates, and evaluate the goodness of fit of the model. In this study, the sample size is quite large $(\mathrm{N}=790)$ and this makes the CHISQ a very rigorous measure of fit (Kline, 2005). Therefore the root mean square error of approximation (RMSEA) and the Comparative Fit Value (CFI) were used in evaluating overall model fit. An RMSEA value, lower than .08 indicates satisfactory fit, and values lower than .05 indicate close fit. A CFI value of over .90 
will indicate good fit (Kline, 2005). Using Mplus, we started with a model based on the mentioned hypotheses, and inspected modification indices for model respecification. Significance of individual parameter estimates was evaluated using the standard errors provided by the Mplus program, using a significance level of $\alpha=.05$.

\section{Results}

\section{Research self-efficacy in four contexts and five phases}

The descriptive analyses show that the lecturers in non-university higher education are rather positive about their own ability to conduct research (82\% scoring 3 or 4 when asked in a single question). The mean score on the total research self-efficacy scale is 3.1. When looking at the four contexts of research, the highest total mean score is for doing research with students (3.4) and the lowest for doing research with external organisations (2.9). When looking at the five aspects of research, the mean scores on designing research are lowest (2.7-3.3) and the mean scores on collecting data are highest (3.0-3.5).

The involvement in research activities differs for the four different contexts. The involvement in research with colleagues, external and self is relatively low (23-34\%), while the involvement in research with students is rather high $(71 \%)$. The need for professional development of lecturers in non-university higher education seems to be high $(50 \%$ in each context). The need for the students context is even as high as $62 \%$.

\section{Insert figure 2 about here}

Results of the path model 
In addition to the lecturers' perception of their own research self-efficacy, several other variables, grouped into three types, were included in the model. The model with relations based on the hypotheses was used as the starting model (figure 2). The fit of the first model with CHISQ $=193.825, \mathrm{df}=64, \mathrm{p}<.05, \mathrm{RMSEA}=.051 \quad(\mathrm{CI} 90 \%=.043-.059), \mathrm{CFI}=.97$ was satisfactory, and therefore accepted as the final model. For all effects, see table 2; for all covariances and residual variances of exogenous variables, see table 3 , and for the endogenous variables see table 4 .

\section{Insert tables 2, 3 and 4 about here}

\section{Explaining research self-efficacy}

In the final structural model, $39 \%$ of the variance in research self-efficacy is explained by the independent variables. Of the three types of independent variables, the first group on personal factors, both age (H1) and gender (H2) did not show a significant effect on research selfefficacy, where positive effects for higher age, and men over women were expected.

The variables of the second group which consists of the factors of mastery experience, educational level (H3), and the involvement in research activities in three out of four contexts (H4) showed a significant positive relation with research self-efficacy. This is as expected and in line with Bandura's theory of Mastery Experience (2006). Doing research elsewhere (H5) and years of educational experience (H6) did not show a significant relation with research selfefficacy: Therefore no difference in research self-efficacy is found between novice and more experienced lecturers. Having research experience outside the teaching institution has no influence on research self-efficacy. The third group on work context (H7 \& H8) showed no significant effects. 
The effect of research self-efficacy on the need to be trained in research activities.

We expected a higher sense of research self-efficacy as an effect on the need to be trained in research activities (H8), because the need to be trained can also be related to different types of motivation for wanting to be trained. The results for the need to be trained in the context of colleagues and the results for the need to be trained for external research activities are in line with some of the previous research: a higher research self-efficacy results in a higher need to be trained (DeForest \& Hughes, 1992; Clifton, 1997; Runhaar et al., 2010). No effect is found for the research self-efficacy on having a need for professional development in the context of individual research. For research training in the context of students another pattern can be seen: a higher research self-efficacy results in a lower need to be educated in research with students, as expected based on the theories of Tschannen-Moral and Hoy (2007) on novice and experienced lecturers. The indirect effects between involvement and professionalization needs show similar dual results (see table 2).

\section{Conclusion \& discussion}

Lecturers in non-university higher education are rather positive about their own ability to conduct research. They feel they are the most capable of doing research with students, and least capable of engaging in research with external organisations. Lecturers find their own abilities in designing research the least developed, and they see the least problems in the data collection phase of research. The need for professional development is rather high as well; $62 \%$ of the lecturers would like to be trained for conducting research with students.

From the structural equation model one can conclude several things. First, the educational level of the lecturers is a very important base for the research self-efficacy of lecturers. Therefore, the trend among Dutch non-university higher education institutions to increase the 
educational level from mainly a (professional) Bachelor level to a (scientific) Master or $\mathrm{PhD}$ level is the right thing to do and should be stimulated by further funding possibilities.

Second, being involved in research has a positive influence on the research self-efficacy of lecturers. On the other hand, doing research outside the institution has no effect on the research self-efficacy of the lecturer. One can conclude that the context in which one can contribute to mastery is important for the sense of self-efficacy in that context. Experiences outside that context do not contribute to mastery. This is in line with Bandura's (2006) concept of the relation between mastery experience and self-efficacy: context matters. Therefore, in addition to increasing the educational level of the lecturers, a way to increase the sense of research capability among lecturers in non-university higher education, is to get them involved in research within their own institutions, especially with students, colleagues, and external organisations.

Thirdly, the concern of some (see Groene \& Steyaert, 2002; Griffioen \& De Jong, 2007) seems unnecessary: working in any context in non-university higher education with a lower level of research surroundings does not result in unrealistic optimism in research capacities, since educational level and research self-efficacy are connected. Also, the influence of being a discipline with a background in research (Health, Social Works) or a discipline that is catching up in this regard (Economics) shows no different effect on the research self-efficacy of lecturers in these sectors. Education and involvement matter for research self-efficacy, disciplinary context does not.

The fourth aspect to consider is the effect of research self-efficacy on the needs for professional development of lecturers in different contexts. The influence of research selfefficacy in this regard is small, so further research should give more insight into what induces lecturers in non-university higher education to want to be trained in research aspects. Previous research (Yorke \& Knight, 2004; Tschannen - Moran \& Hoy, 2007; Runhaar et al., 2010) 
showed a positive effect of self-efficacy on the need for professional development: the higher the degree of self-efficacy, the more positive the attitude towards educational activities. This pattern can be seen in this study for research with colleagues and external partners (commercial and non-commercial companies), but not for research with students, where a higher selfefficacy results in a lower developmental need. Further research, in which different motivational orientation (performance or goal) should be included (Runhaar et al., 2010), will be very helpful in this regard. Another aspect to include is the possible feeling of incompetence of the proportion of the lecturers who have no research experience, and competence of those who do have research experience. The research activities were mainly externally imputed by national and European policy, and not primarily grown out of the individual changing professions. Lecturers who only teach and have had no research experience, can feel they need to be educated in conducting research with students, because it no longer seems a 'free-tochoose' activity in addition to teaching. More experienced lecturers feel they can (and want to) become better in conducting research in the contexts of colleagues and external organisations. If this is the case, research with colleagues and external parties is seen as a 'more advanced' activity, while research with students is of a more 'basic level'. All of these possible explanations have to be tested in further research. Meanwhile, local educational managers need to be aware of this kind of differences in discussing teaching and research tasks, as well as professionalization trajectories with individual lecturers (see also Boerma, Griffioen et al., 2011). Managers also need to be aware of the influence of their leadership styles on the research self-efficacy of lecturers (Griffioen, De Jong et al. In review).

To conclude, one can say that getting lecturers involved in research activities in their own institutions will increase their sense of competence in conducting research (see also Cousin \& Deepwell, 2006). Bandura (1997) concluded that lecturers with lower self-efficacy are more reluctant towards change. So, increasing the participation of lecturers in research activities can 
increase their feeling of research competence. This possibly increases the speed of the current innovation into becoming more research based institutions, because lecturers are at the root of changing non-university higher education into more research-based organisations (Van den Berg, Sleegers, Geijsel \& Vandenberghe, 2000; Runhaar, 2008). This research shows that when research training is offered to lecturers, research self-efficacy should be accounted for. The combination with learning to conduct research 'on the job' could be preferable, also to the lecturers themselves (see for instance Henson, 2001). If this can be combined with increasing the actual knowledge of lecturers on how to conduct research, by increasing their formal level of education, this may also prove to be effective.

\section{Notes on the contributors:}

Didi Griffioen is a senior policy advisor in applied research at the Amsterdam University of Applied Sciences, and a PhD-student at the University of Amsterdam.

Uulkje de Jong is a senior researcher on higher education at the University of Amsterdam.

Suzanne Jak is a PhD-student in methodology at the University of Amsterdam.

\section{References}

Bandura, A. (1997). Self-efficacy: The exercise of control. New York, W.H. Freeman.

Bandura, A. (2006). Guide for constructing self-efficacy scales. In F. Pajares \& T. Urdan (Eds.) Selfefficacy beliefs of adolescents (Vol. 5. pp 307- 337) Greenwich, CT: Information Age Publishing.

Boerma, K., Griffioen, D. M. E., et al. (2011, August - September). The executive's standard on research competence of teachers in Dutch non-university Higher Education', as part of the symposium 'Research in non-university Higher Education: Perceptions on Research Competence and its Importance. The bi-annual conference of the European Association for Research on Learning and Instruction (EARLI). Exeter, UK. 
Brouwer, I., (Ed.) (2003). Het glazen plafond: vrouwen aan de top, verlangens \& obstakels. Amsterdam, Boom.

Busch, T., Fallan, L., \& Peterson, A. (1998). Disciplinary differences in job satisfaction, self-efficacy, goal commitment and organisational commitment among faculty employees in Norwegian colleges: An empirical assessment of indicators of performance. Quality in Higher Education 4(2), $137-157$.

Clifton, J. (1997). Constraining influences on the decision to participate in training: The importance of the non-work environment. Working Paper Series. Ithaca, CAHRS, Cornell University: 31.

Cousin, G., \& Deepwell, F. (2006). Designs for network learning: a communities of practice perspective. Studies in Higher Education 30(1): 57-66.

DeForest, P. A., \& Hughes, J. N. (1992). Effect of teacher involvement and teacher self-efficacy on ratings of consultant effectiveness and intervention acceptability. Journal of Educational and Psychological Consultation, 3, 301-316.

Dembo, M. H., \& Gibson, S. (1985). Teachers' sense of efficacy: An important factor in school improvement. The Elementary School Journal, 86(2), 173 - 184.

Ghaith, G., \& Yaghi, H. (1997). Relationships among experience, teacher efficacy, and attitudes toward the implementation of instructional innovation. Teaching and teacher education : an international journal of research and studies, 13(4), 451 - 458.

Griffioen, D. M. E., \& Boei, F. (2010). Promoveren in het hoger beroepsonderwijs: Een stand van zaken. TH\&MA.

Griffioen, D. M. E. \& De Jong, U. (2007). De positie van onderzoek in het HBO; geschiedenis van een discussie. [The place of research in non-university Higher Education; a history of the debate]. Onderwijs Research Dagen. Groningen, GION.

Griffioen, D. M. E., \& De Jong, U. (2008). Onderzoek door het Hoger Beroepsonderwijs in Nederland: visie op onderzoek. Medewerkers van de Hogeschool van Amsterdam over doelen van 
onderzoek en zichtbaarheid van resultaten in de eigen omgeving. Onderwijs Research Dagen. Eindhoven.

Griffioen, D. M. E., De Jong, U., et al. (in review). The influence of leadership and participation on the research perceptions of lecturers in non-university Higher Education.

Groene, A., de., \& Steyaert, J. (2002). Kleine mythologie van onderzoek in het HBO [Small mythology of research in professional Higher Education].

HBO-raad. (2010). Feiten en cijfers, kengetallen personeel. Retrieved Februari 12, 2010, from http://www.hbo-raad.nl/hbo-raad/feiten-en-cijfers/cat_view/60-feiten-en-cijfers/62bedrijfsvoering/66-personeel.

Henson, R. K. (2001). The effects of participation in teacher research on teacher efficacy. Teaching and teacher education : an international journal of research and studies, 17(7), 819-836.

Hofman, A., Boom, J. de, Heyl, E., Jong, U. de, Veen, I. van der, Voorthuis, M., Leeuwen, M. van, Korteweg, J.A. \& Budil-Nadvorniková, H. . (2002). Studentenmonitor 2001. Studenten in het Hoger Onderwijs. Ministerie van Onderwijs Cultuur en Wetenschappen. Den Haag.

Hoy, A. W., \& Spero, R. B. (2005). Changes in teacher efficacy during the early years of teaching: A comparison of four measures. Teaching and teacher education : an international journal of research and studies, 21(4), 343 - 356.

Kline, R. B. (2005). Principles and practise of structural equation modelling. New York, London, The Guiford Press.

Kyvik, S. (2004). Structural changes in Higher Education systems in western Europe. Higher Education in Europe, 29(3), 393-409.

Kyvik, S., \& Skodvin, O. J. (2003). Research in non-university Higher Education sector - tensions and dilemmas. Higher Education, 45, 203-222.

Muthén, L. K., \& Muthén, B. O. (2007). Mplus users guide. Los Angeles, CA: Muthén \& Muthén. 
Netherlands Economic Institute. (2011). History of NEI. Retrieved from http://www.nei.nl/profiel/history.html.

Noble, K. D. (1987). The dilemma of the gifted women. Psychology of Women Quarterly, 11(3), 367 $-378$.

Noe, R. A., \& Wilk, S. L. (1993). Investigation of factors that influence employees' participation in development activities. Journal of Applied Psychology, 78(2), 291-302.

Runhaar, P. (2008). Promoting teachers' professional development. . Enschede, Piety Runhaar.

Runhaar, P., Sanders, K., \& Yang, H. (2010). Stimulating teachers' reflection and feedback asking: An interplay of self-efficacy, learning goal orientation, and transformational leadership. Teaching and teacher education : an international journal of research and studies, 26, 11541161.

Tschannen - Moran, M., \& Hoy, A. W. (2007). The differential antescedents of self-efficacy beliefs of novice and experienced teachers. Teaching and teacher education :An international journal of research and studies, 23(6), 944 - 956.

Van den Berg, R., Sleegers, P., Geijsel, F., \& Vandenberghe,. R. (2000). Implementation of an innovation: Meeting the concerns of teachers. Studies in Educational Evaluation, 26, 331-350.

Witte, J., M. Van der Wende, M., \& Huisman, J. (2008). Blurring boundaries: How the Bologna Process changes the relationship between university and non-university Higher Education in Germany, The Netherlands and France. Studies in Higher Education, 33(3), 217-231.

Yorke, M., \& Knight, P. (2004). Self-theories: some implications for teaching and learning in higher education. Studies in Higher Education, 29(1), 25-37. 